\title{
Therapeutic Vascular Angiogenesis for Vasculitis Related Peripheral Artery Disease
}

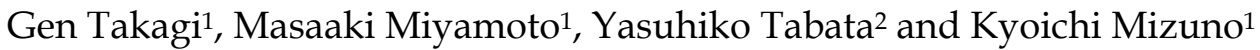 \\ ${ }^{1}$ Nippon Medical School, \\ ${ }^{2}$ Kyoto University \\ Japan
}

\section{Introduction}

The increasing morbidity due to peripheral artery disease (PAD) has given rise to a recent focus in cardiovascular medicine, and strategies for peripheral intervention have proliferated. For example, distal bypass, and catheter intervention for below-knee arteries have been performed aggressively. Also, there has been detailed research on the mortality of peripheral artery disease. In fact, it is reported that the mortality of PAD is higher than that of colon cancer. In a the patient with complicated PAD, even leg amputation does not prevent adverse events (Cruz, 2003; Aulivola, 2004). In this context, the discovery of other options for peripheral intervention is an impending. Also, patients may have various other diseases or a condition underlying the ischemic insult. Among these, vasculitis and collagen disease are often associated with difficult ischemic conditions. In these cases, there are limited options for treatment. Here we describe new techniques to achieve peripheral circulation including vascular angiogenesis, and explain the potential mechanism and effectiveness including that in vasculitis patients.

\section{Guidelines for peripheral artery disease}

Guidelines for peripheral artery disease have been published by the Trans Atlantic InterSociety Consensus (Hirsch, 2006). In these guidelines, a treatment strategy was precisely determined. However, there is still no established evidence regarding treatment for belowknee arterial ischemia, especially for patients with critical limb ischemia (CLI), which is intractable limb ischemia due to PAD, who immediately face limb amputation. Catheter intervention and distal bypass grafting are well known to improve distal ischemia; however, however in specific conditions such as vasculitis or collagen disease, which is the focus of this chapter, the location of the occluded artery is mainly distal to the ankle or wrist which makes it difficult to treat with these strategies, and also, due to the pathogenesis of the original disease, the target vessels often become reoccluded soon after treatment.

\section{Diagnosis and definition of severity}

Definitive diagnosis should be made by documentation of the affected tissue. In order to make the correct diagnosis, biopsy of abnormal or symptomatic tissue is reliable. In patients with proven vasculitis, the diagnostic yield from biopsies of clinically normal sites is 
considerably less than $20 \%$. In addition, when a wound is complicated by vasculitis or collagen disease, the invasive nature of by biopsy itself worsens the wound, and it is usually difficult to obtain a tissue sample unless amputation tissue is available.

In order to perform correct diagnosis and appropriate treatment, it is necessary to define the severity of ischemia using a reliable and safe method. Ankle-brachial index (ABI) is one of the useful screening methods for PAD. However, the data are inconsistent when the artery is severely calcified, which is known as Mönckeberg sclerosis (figure 1), which shows a pseudo-normalized value. Also, ABI is not a suitable method to define the amputation level. Skin perfusion pressure(SPP), obtained by digitized quantification of blood flow, is a reliable method that is also useful to define the amputation level. However, in vasculitis or collagen disease, it is difficult to apply because most patients experience excruciating pain, and cuff inflation may worsen the patient's condition. Thus, there is no clear consensus regarding an evaluation method for CLI. One of the potential less invasive approaches to analyze blood flow level is, analyze radio-isotope imaging by $99 \mathrm{~m}$ technetium-tetrofosmin (99mTc-TF) perfusion scintigraphy (Miyamoto, 2004). Furthermore, in consideration of repeatability, cost effectiveness, and minimum stimulation to the ischemic area, we propose transcutaneous oxygen tension $\left(\mathrm{TcPO}_{2}\right)$ as the most useful method. It requires only electrode placement on the skin surface, and is suitable to examine distal ischemia even if the ischemic region is located below the ankle. The disadvantage of $\mathrm{TcPO}_{2}$ is the influence of the environment such as surrounding temperature or patient condition. In order to avoid possible error in detection, we propose that "maximum $\mathrm{TcPO}_{2}$ " could clarify the result, and we believe the environmental influence could be minimized by data acquisition during 100\% oxygen inhalation (Tara, 2011a).

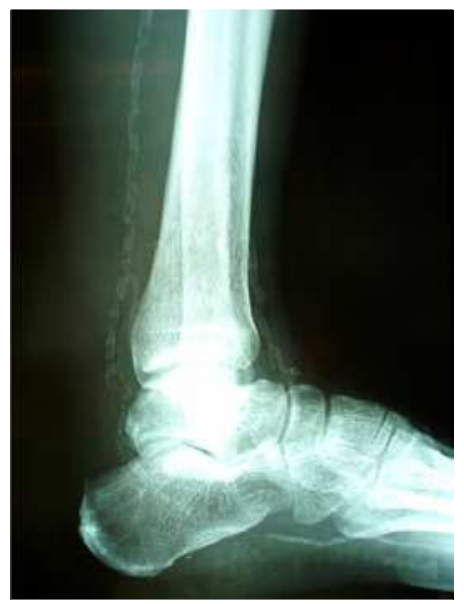

Fig. 1. X-ray of leg. Representative case of Mönckeberg sclerosis. Vascular calcification and its location are well defined without contrast medium.

\section{Novel approach}

Due to pathogenesis of vasculitis, such as rheumatoid arthritis or collagen disease, vascular involvement mainly occurs in distal microvessels. Furthermore, the vasculitides are defined by the presence of an inflammatory process in the vessel wall, with reactive damage to mural structures. Often direct vascular stimulation by surgical or catheter intervention of 
small vessels causes acute thrombosis or closure of the vessels. Also, according to the TASC guidelines, an intervention strategy has not been established for vasculitis. One of the recent topics is vascular regenerative therapy for PAD through the implantation of autologous bone marrow mononuclear cells into the ischemic area. In this context, the topic has been extended to secondary PAD due to vasculitis. In Japan, there has been a pilot study regarding bone marrow-derived stem cell implantation for collagen disease-related peripheral ischemia (Kamata, 2007; Takahashi, 2009). On the other hand, it was reported that endothelial progenitor cell function is inhibited, in collagen disease such as SLE patients treated with corticosteroids (Grisar, 2008), and also production of angiogenic factors from bone marrow cells is suppressed (Greenberger; Nauck, 1998). In addition, collected bone marrow would include a substantial amount of activated dendrocytes and immune stimulating cytokines such as interferon gamma which may worsen an ischemic ulcer. Thus, we focused on a more specific approach to vasculitis or collagen disease in order to establish a more safe and effective approach.

\section{Growth factor approach}

One strategy is to deliver recombinant proteins directly to the ischemic tissue by intramuscular or intraarterial injection. An alternate strategy is to use gene therapy, by direct transfer of expression vectors with either virus or naked plasmid. An optimal delivery strategy has not been established, and the approach of using a large amount of protein or gene as a therapeutic agent has several disadvantages. Also, the outcomes of early-phase clinical trials with a particular molecule have been less than encouraging, possibly because of factors such as the selection and formulation of the growth factor, duration of exposure, route of administration, and selection of patients. On the basis of our experiences, bone marrow mononuclear cell implantation in patients with complicated CLI is effective (Miyamoto, 2004). Regarding the mechanism, our colleague demonstrated potential cytokines produced from bone marrow mononuclear cells in response to ischemia (Uemura, 2006). Among these growth factors such as basic fibroblast growth factor (b-FGF), vascular endothelial growth factor (VEGF), and insulin-like growth factor (IGF), only b-FGF has a strong angiogenic property (Doi, 2007) and human recombinant b-FGF is available to purchase for clinical use in Japan. Furthermore, as b-FGF is a water soluble compound, Tabata et al (Tabata, 1998) developed a drug delivery system (DDS), utilizing b-FGF conjugated with gelatin hydrogel by chemical cross-linking that enables slow release of bFGF over two weeks. The precise method of gelatin hydrogel preparation (Figure 2) has been previously described (Tara, 2011b), in brief, gelatine microspheres were impregnated with an aqueous solution containing recombinant human b-FGF followed by leaving at $4{ }^{\circ} \mathrm{C}$ for over 12 hours to obtain b-FGF-incorporated gelatine hydrogel. Under general anesthesia, we injected prepared b-FGF $(600 \mu \mathrm{g})$-incorporated gelatin hydrogel directly into the calf muscle at twenty sites around the ulcer under Doppler echo-guidance.

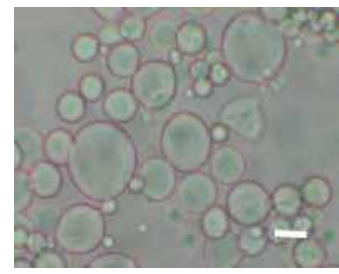

Fig. 2. Gelatin microspheres. White bar indicates $20 \mu \mathrm{m}$. 


\section{Our experience of novel treatment for vasculitis}

\subsection{Churg-Strauss syndrome}

Churg-Strauss syndrome (CSS; allergic angitis and granulomatosis) is a rare syndrome that is occasionally complicated by cutaneous, and vascular involvement which shows characteristic histopathologic findings (Figure 3-A). Vasculitis involves the microcirculation, often with intractable cutaneous ulcers (Figure 3-B), and when vascular involvement occurs at the visible artery level (Figure 3-C), standard corticosteroid treatment is less effective. Often the ulcer is complicated by antibiotics-resistant bacterial infection, which makes it difficult to continue or increase the corticosteroid dose. We injected 600 $\mu \mathrm{g}$ b-FGF protein into the calf muscle, and the ulcer had healed 15 weeks later (Figure 3-D) (Kawanaka, 2009).

\subsection{Systemic lupus erythematosus (SLE)}

SLE is a systemic autoimmune disease characterized by the presence of immune complexes, autoantibodies and anti-nuclear antibody ANA), sometimes with cardiovascular involvement such as coronary arteritis or small arterial disease. Our case had an intractable ulcer above the lateral malleolus (Figure 4-A). Digital subtraction angiography revealed total occlusion of the right anterior tibial artery, right posterior tibial artery and right peroneal artery. The dorsalis pedis artery showed hardly any flow, and was supplied by collateral circulation (Figure 4-B). We injected $600 \mu \mathrm{g}$ b-FGF protein into the calf muscle and the ulcer had healed 4 weeks later (Figure 4-C) (Tara, 2011b).

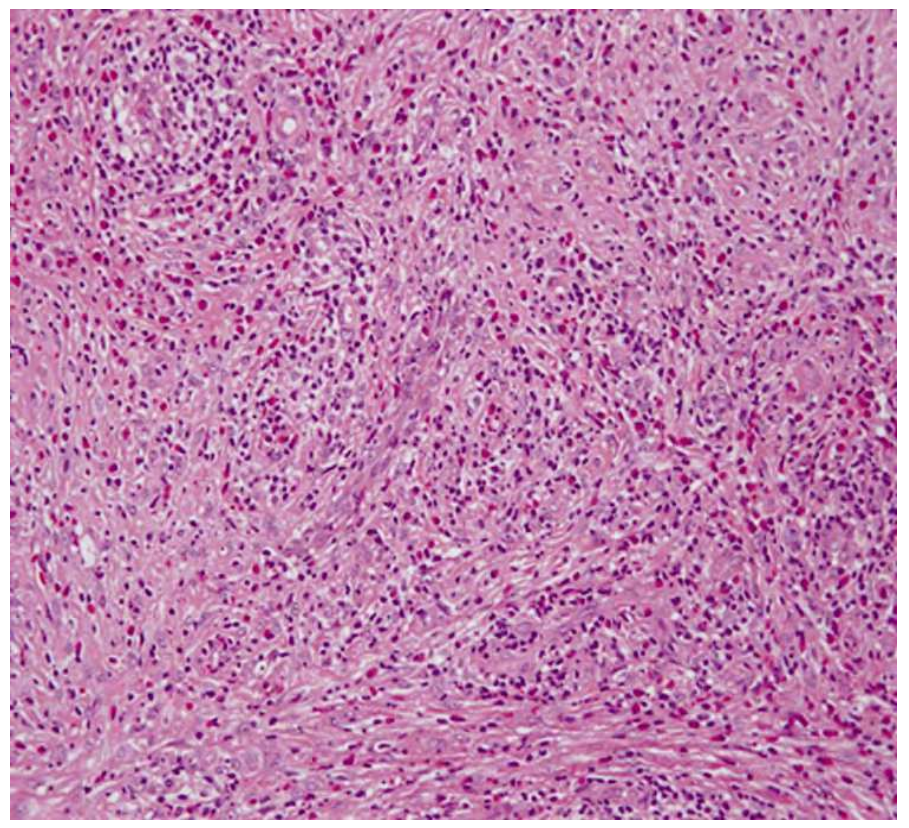

Fig. 3.A. Histological findings. Pathologic examination revealed vasculitis of small arteries and capillaritis with eosinophils as well as chronic inflammatory granulation-like changes in fibrous connective tissue. 


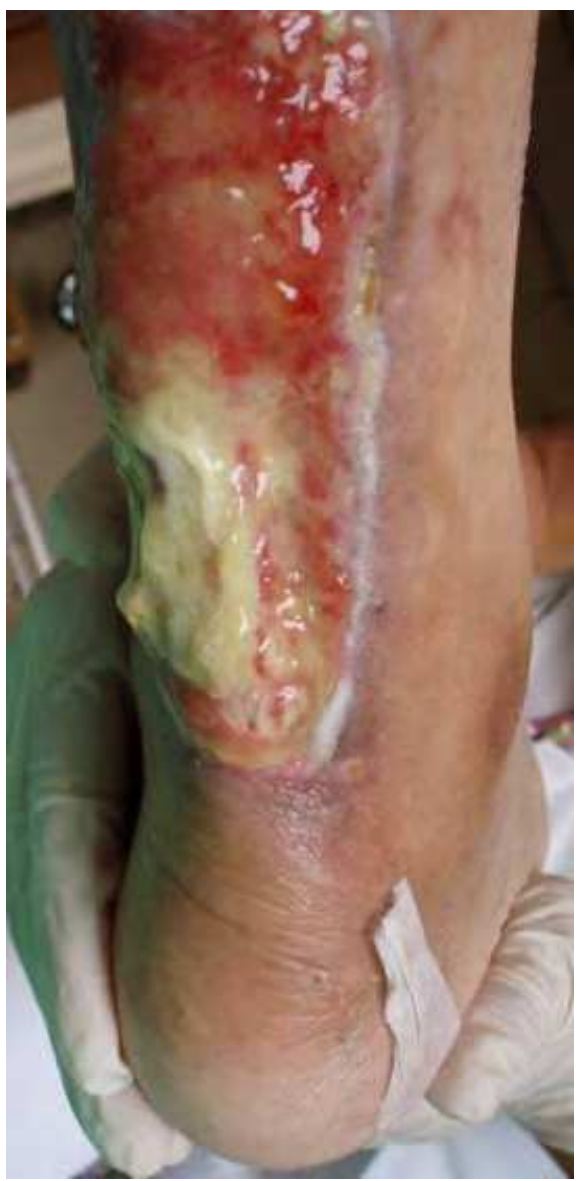

Fig. 3. B. Patient with Churg-Strauss syndrome. Photographs show right lower calf ulcer that did not respond to topical and medical treatment.

\section{Discussion}

Among the vasculitides, we experienced cases of Churg-Strauss syndrome and SLE complicated by intractable ulcers. A DDS designed to provide controlled- release b-FGF protein mono-therapy successfully improved those ulcers and avoided major amputation. Leg ulcers complicate many conditions including ischemia and infection, and the location of ischemia varies among different diseases. Considering the pathogenesis of vasculitis, this protein - based angiogenesis therapy is less invasive, repeatable, safe and effective. Utilization of this DDS approach would be a powerful approach for vasculitis - related intractable ulcer. We recommend this controlled-release b-FGF protein therapy when the ulcer does not respond to usual corticosteroid therapy and when ischemia is documented angiographically. In the future, we plan to establish a multi-growth factor approach to enhance local circulation and wound healing in intractable ulcers. 


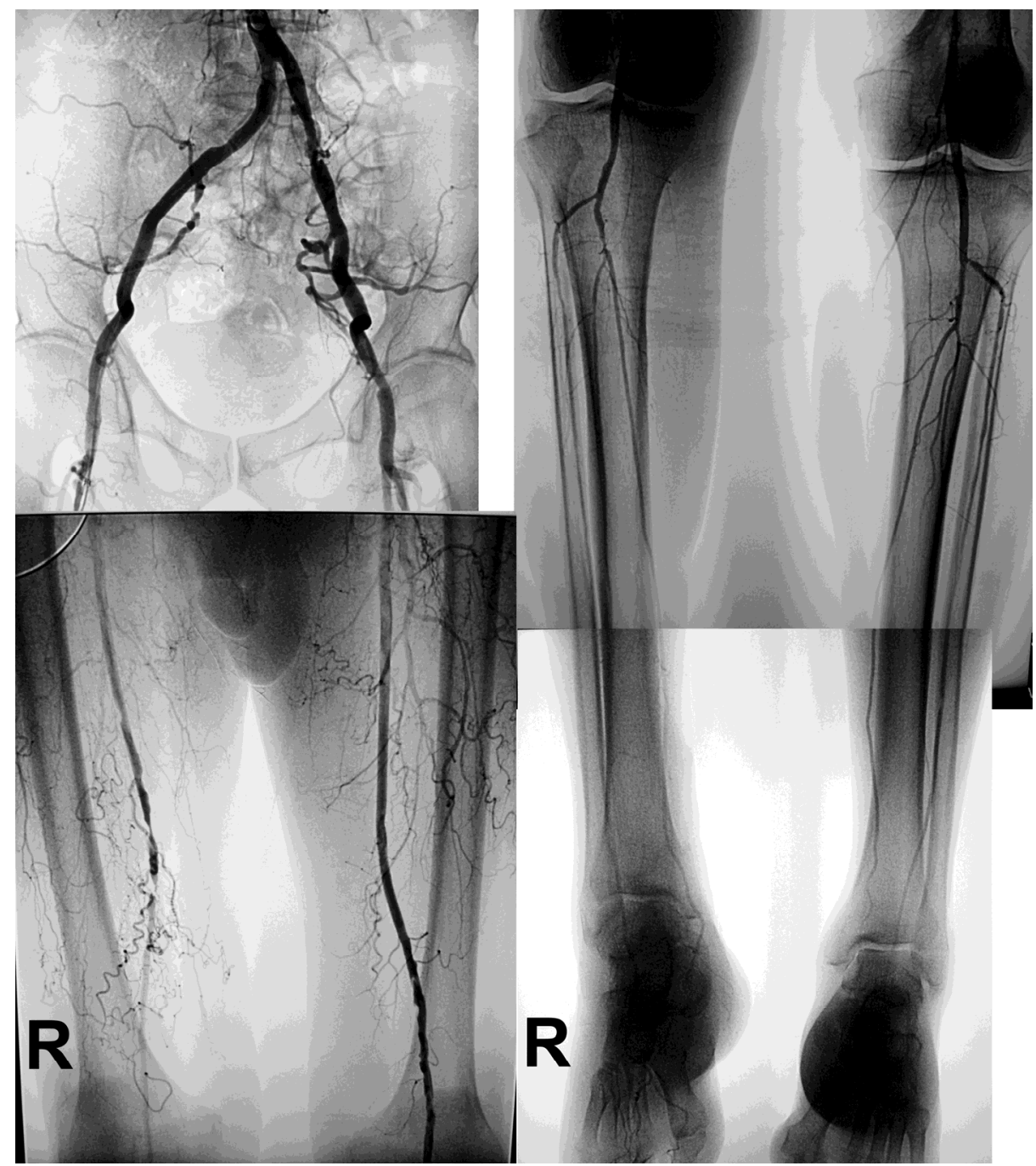

Fig. 3. C. Digital subtraction angiographic findings. Total occlusion of the right superficial femoral artery is shown. 


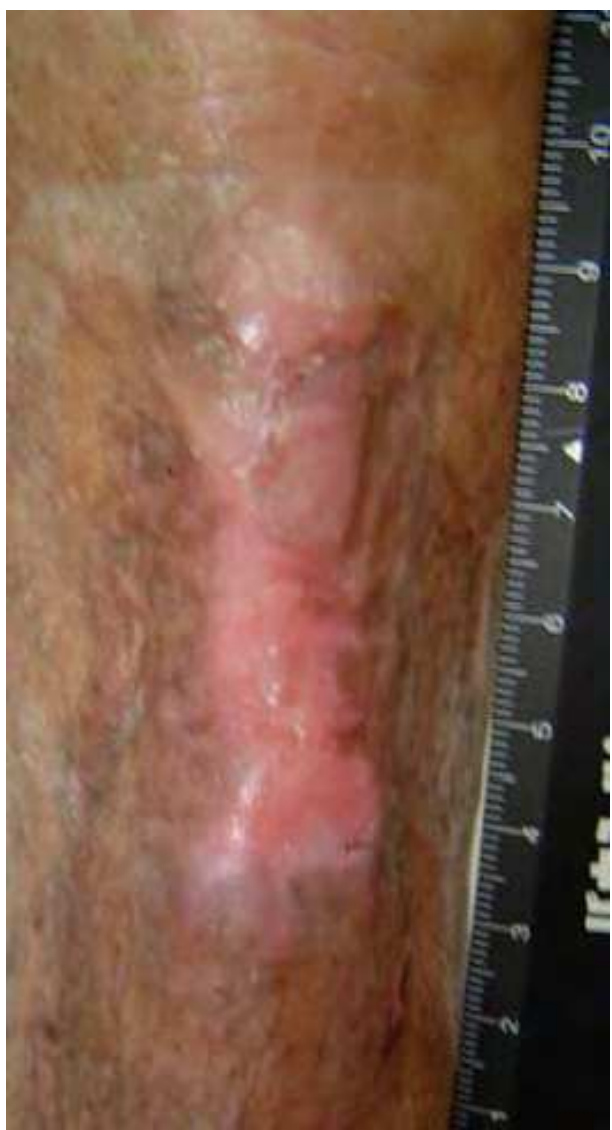

Fig. 3. D. Skin ulcer after treatment. The skin ulcer had healed completely 15 weeks after treatment.

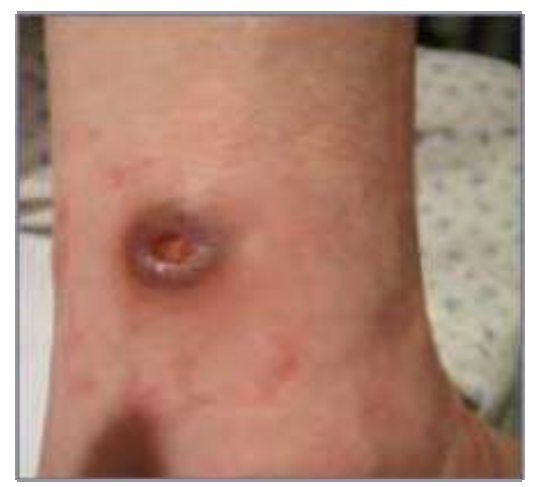

Fig. 4. A. Patient with SLE. The photograph shows a skin ulcer above the right lateral malleolus. 


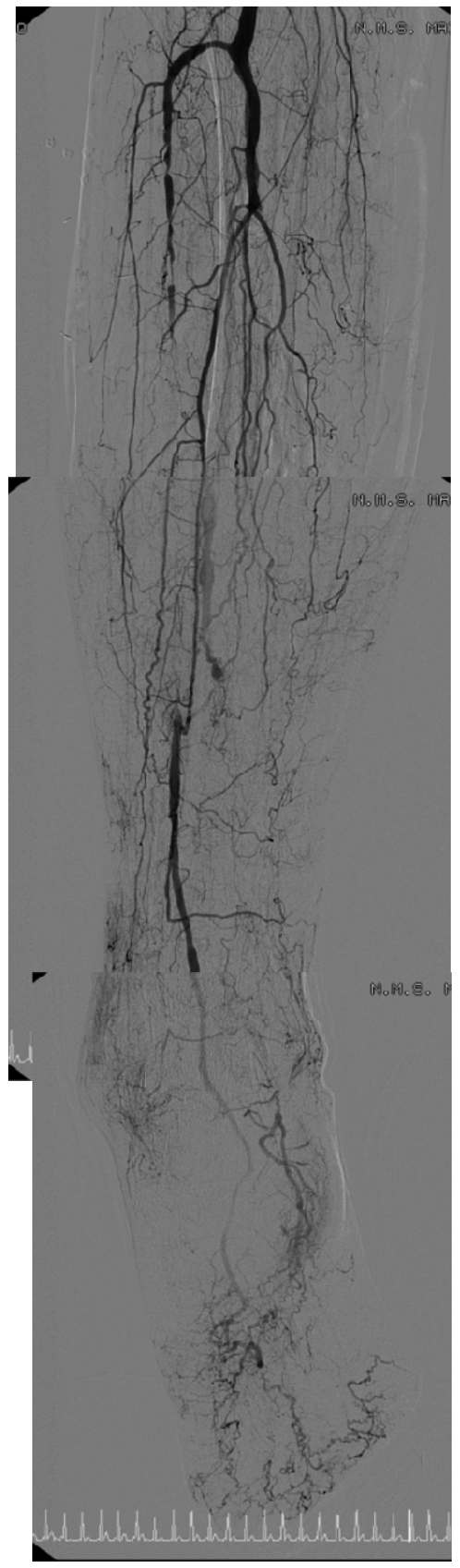

Fig. 4. B. Digital subtraction angiographic findings. Total occlusion of the right anterior tibial artery, right posterior tibial artery and right peroneal artery is shown. The dorsalis pedis artery was enhanced by collateral circulation 


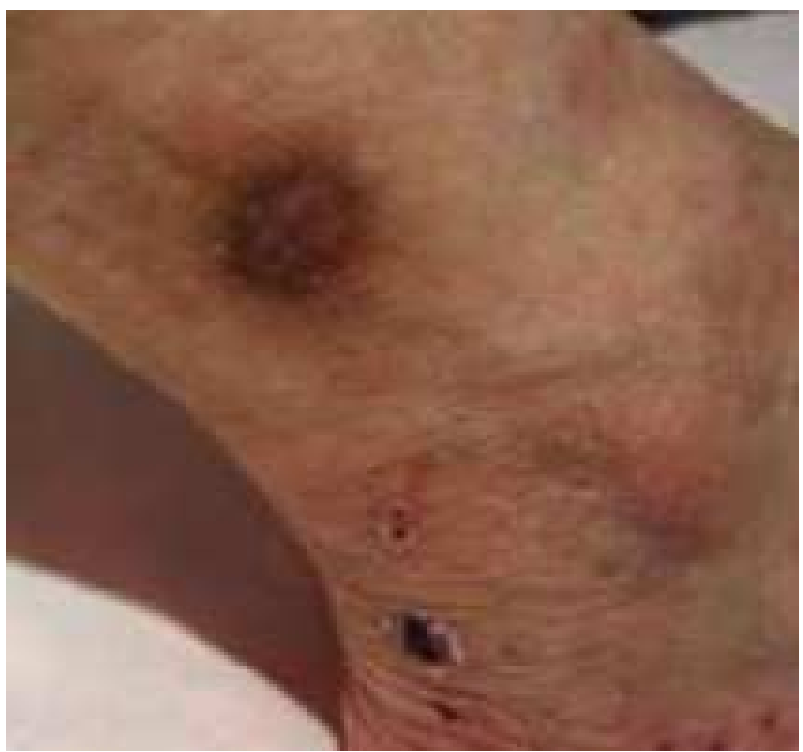

Fig. 4. C. SLE ulcer after treatment. The skin ulcer had healed completely 4 weeks after treatment.

\section{Conclusion}

Controlled-release b-FGF administration successfully healed ischemic skin ulcers and improved local skin blood perfusion in patients with vasculitis or collagen disease. Our findings suggest a novel clinical approach for ischemic skin ulcer associated with vasculitis or collagen disease.

\section{References}

Aulivola B, Hile CN, Hamdan AD, Sheahan MG, Veraldi JR, Skillman JJ, Campbell DR, Scovell SD, LoGerfo FW \& Pomposelli FB, Jr. (2004). Major lower extremity amputation: outcome of a modern series. Arch Surg 139, 395-399; discussion 399.

Cruz CP, Eidt JF, Capps C, Kirtley L \& Moursi MM. (2003). Major lower extremity amputations at a Veterans Affairs hospital. Am J Surg 186, 449-454.

Doi K, Ikeda T, Marui A, Kushibiki T, Arai Y, Hirose K, Soga Y, Iwakura A, Ueyama K, Yamahara K, Itoh H, Nishimura K, Tabata Y \& Komeda M. (2007). Enhanced angiogenesis by gelatin hydrogels incorporating basic fibroblast growth factor in rabbit model of hind limb ischemia. Heart Vessels 22, 104-108.

Greenberger S, Boscolo E, Adini I, Mulliken JB \& Bischoff J. Corticosteroid suppression of VEGF-A in infantile hemangioma-derived stem cells. N Engl J Med 362, 1005-1013.

Grisar J, Steiner CW, Bonelli M, Karonitsch T, Schwarzinger I, Weigel G, Steiner G \& Smolen JS. (2008). Systemic lupus erythematosus patients exhibit functional deficiencies of endothelial progenitor cells. Rheumatology (Oxford) 47, 1476-1483.

Hirsch AT, Haskal ZJ, Hertzer NR, Bakal CW, Creager MA, Halperin JL, Hiratzka LF, Murphy WR, Olin JW, Puschett JB, Rosenfield KA, Sacks D, Stanley JC, Taylor LM, Jr., White CJ, 
White J, White RA, Antman EM, Smith SC, Jr., Adams CD, Anderson JL, Faxon DP, Fuster V, Gibbons RJ, Hunt SA, Jacobs AK, Nishimura R, Ornato JP, Page RL \& Riegel B. (2006). ACC/AHA 2005 guidelines for the management of patients with peripheral arterial disease (lower extremity, renal, mesenteric, and abdominal aortic): executive summary a collaborative report from the American Association for Vascular Surgery/Society for Vascular Surgery, Society for Cardiovascular Angiography and Interventions, Society for Vascular Medicine and Biology, Society of Interventional Radiology, and the ACC/AHA Task Force on Practice Guidelines (Writing Committee to Develop Guidelines for the Management of Patients With Peripheral Arterial Disease) endorsed by the American Association of Cardiovascular and Pulmonary Rehabilitation; National Heart, Lung, and Blood Institute; Society for Vascular Nursing; TransAtlantic Inter-Society Consensus; and Vascular Disease Foundation. J Am Coll Cardiol 47, 1239-1312.

Kamata Y, Takahashi Y, Iwamoto M, Matsui K, Murakami Y, Muroi K, Ikeda U, Shimada K, Yoshio T, Okazaki H \& Minota S. (2007). Local implantation of autologous mononuclear cells from bone marrow and peripheral blood for treatment of ischaemic digits in patients with connective tissue diseases. Rheumatology (Oxford) 46, 882-884.

Kawanaka H, Takagi G, Miyamoto M, Tara S, Takagi I, Takano H, Yasutake M, Tabata Y \& Mizuno K. (2009). Therapeutic angiogenesis by controlled-release fibroblast growth factor in a patient with Churg-Strauss syndrome complicated by an intractable ischemic leg ulcer. Am J Med Sci 338, 341-342.

Miyamoto M, Yasutake M, Takano H, Takagi H, Takagi G, Mizuno H, Kumita S \& Takano T. (2004). Therapeutic angiogenesis by autologous bone marrow cell implantation for refractory chronic peripheral arterial disease using assessment of neovascularization by $99 \mathrm{mTc}$-tetrofosmin (TF) perfusion scintigraphy. Cell Transplant 13, 429-437.

Nauck M, Karakiulakis G, Perruchoud AP, Papakonstantinou E \& Roth M. (1998). Corticosteroids inhibit the expression of the vascular endothelial growth factor gene in human vascular smooth muscle cells. Eur J Pharmacol 341, 309-315.

Tabata Y, Yamada K, Miyamoto S, Nagata I, Kikuchi H, Aoyama I, Tamura M \& Ikada Y. (1998). Bone regeneration by basic fibroblast growth factor complexed with biodegradable hydrogels. Biomaterials 19, 807-815.

Takahashi M, Izawa A, Ishigatsubo Y, Fujimoto K, Miyamoto M, Horie T, Aizawa Y, Amano J, Minota S, Murohara T, Matsubara H \& Ikeda U. (2009). Therapeutic neovascularization by the implantation of autologous mononuclear cells in patients with connective tissue diseases. Curr Pharm Des 15, 2778-2783.

Tara S, Miyamoto M, Takagi G, Fukushima Y, Kirinoki-Ichikawa S, Takano H, Takagi I, Mizuno H, Yasutake M, Kumita S \& Mizuno K. (2011a). Prediction of limb salvage after therapeutic angiogenesis by autologous bone marrow cell implantation in patients with critical limb ischemia. Ann Vasc Dis 4, 24-31.

Tara S, Takagi G, Kirinoki-Ichikawa S, Yamamoto T, Takano H, Takagi I, Yasutake M, Miyamoto M, Tabata Y \& Mizuno K. (2011b). Novel approach to ischemic skin ulcer in systemic lupus erythematosus: Therapeutic angiogenesis by controlledrelease basic-fibroblast growth factor. Geriatr Gerontol Int in press.

Uemura R, Xu M, Ahmad N \& Ashraf M. (2006). Bone marrow stem cells prevent left ventricular remodeling of ischemic heart through paracrine signaling. Circ Res 98, 1414-1421. 


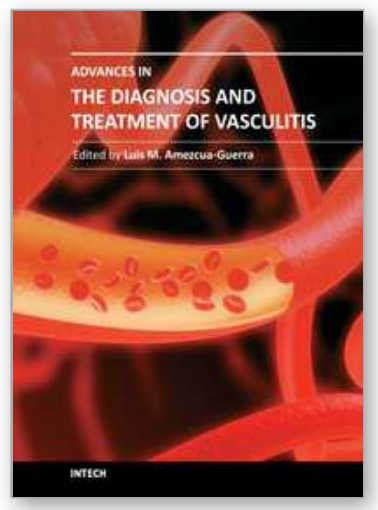

\author{
Advances in the Diagnosis and Treatment of Vasculitis \\ Edited by Dr. Luis M Amezcua-Guerra
}

ISBN 978-953-307-786-4

Hard cover, 366 pages

Publisher InTech

Published online 09, November, 2011

Published in print edition November, 2011

This book represents the culmination of the efforts of a group of outstanding experts in vasculitis from all over the world, who have endeavored to draw themselves into this volume by keeping both the text and the accompanying figures and tables lucid and memorable. The book provides practical information about the screening approach to vasculitis by laboratory analysis, histopathology and advanced image techniques, current standard treatment along with new and more specific interventions including biologic agents, reparative surgery and experimental therapies, as well as miscellaneous issues such as the extra temporal manifestations of "temporal arteritis" or the diffuse alveolar hemorrhage syndrome. The editor and each of the authors invite you to share this journey by one of the most exciting fields of the medicine, the world of Vasculitis.

\title{
How to reference
}

In order to correctly reference this scholarly work, feel free to copy and paste the following:

Gen Takagi, Masaaki Miyamoto, Yasuhiko Tabata and Kyoichi Mizuno (2011). Therapeutic Vascular Angiogenesis for Vasculitis Related Peripheral Artery Disease, Advances in the Diagnosis and Treatment of Vasculitis, Dr. Luis M Amezcua-Guerra (Ed.), ISBN: 978-953-307-786-4, InTech, Available from: http://www.intechopen.com/books/advances-in-the-diagnosis-and-treatment-of-vasculitis/therapeutic-vascularangiogenesis-for-vasculitis-related-peripheral-artery-disease

\section{INTECH}

open science | open minds

\section{InTech Europe}

University Campus STeP Ri

Slavka Krautzeka 83/A

51000 Rijeka, Croatia

Phone: +385 (51) 770447

Fax: +385 (51) 686166

www.intechopen.com

\section{InTech China}

Unit 405, Office Block, Hotel Equatorial Shanghai

No.65, Yan An Road (West), Shanghai, 200040, China

中国上海市延安西路65号上海国际贵都大饭店办公楼 405 单元

Phone: +86-21-62489820

Fax: $+86-21-62489821$ 
(C) 2011 The Author(s). Licensee IntechOpen. This is an open access article distributed under the terms of the Creative Commons Attribution 3.0 License, which permits unrestricted use, distribution, and reproduction in any medium, provided the original work is properly cited. 